\title{
A Comparative Approach to Madame Bovary and Kiralik Konak in Terms of Alienation
}

\author{
Ayten ER \\ Gazi University, Ankara, Turkey
}

\begin{abstract}
One's alienation from herself/himself and the society in which she/he lives is a common theme in literature. Though alienation begins with the disharmony, or anomaly, between the society and individual, it usually ends up with the individual's distanciation from the society and retreat into her/his private and inner space. Yet s/he cannot get rid of the problems surrounding her/him and experiences a disastrous end. In this sense, the novel Madame Bovary by Gustave Flaubert, a nineteenth-century French novelist, and Kiralık Konak (The Mansion for Sale) by Yakup Kadri Karaosmanoglu, a twentieth-century Turkish writer, are two ideal examples for this theme in that the protagonists of these two novels are alienated from themselves and their society. This study is intended to make a comparative analysis of these two novels on the basis of the term "alienation" in the light of Emile Durkheim's views of the issue.
\end{abstract}

Keywords: Emma, Seniha, alienation, culture, Flaubert, Karaosmanoğlu

\section{Introduction}

Alienation can be roughly defined as "an action or event that estranges someone or something from someone or something else and makes them foreign to others", but it is more precisely used to mean "the state of things and objects appearing foreign, remote and irrelevant to the conscious, and people's indifference to, weariness of, repulsion to or lack of interest in what they formerly valued and cared and in those with whom they were friends in the past" (Cevizci, 1996, p. 710).

Madame Bovary written by Gustave Flaubert, one of the outstanding writers of French literature, and Kiralık Konak by Yakup Kadri Karaosmanoglu, one of the most popular writers of Turkish literature, are two proper examples to the special dimension of the concept of alienation. In these two novels that are much alike from many aspects, there are two female protagonists, Emma and Seniha, who are worth analyzing in terms of their alienation both from the society and from themselves. The female protagonist of Madame Bovary is Emma, a character in France in the 19th century, while that of Kirallk Konak is Seniha in Istanbul of the 20th century, when Turkey was experiencing an intense emulation for the Western way of life.

Alienation begins with the disharmony, or anomaly, between the society and individual. Merton describes anomaly as the deviation, tension and split between "cultural structure" (Ergin, 1983, p. 5), which consists of the norms, values and objectives accepted by the society, and "social structure or environment" that is the relationship between the individuals' social attitudes to each other; as such, anomaly is the first stage of

Ayten ER, Ph.D., Professor, Faculty of Letters, Department of Western Languages and Literatures, Scholar of French Language and Literature, Gazi University, Ankara, Turkey. 
alienation, followed by social alienation and self-alienation.

The most important factor that splits and alienates them from their surroundings is the books that they read. The impeccable luxurious life and ideal love in these books does not fit in with their real lives, and this contrast pushes them into social alienation. Both Emma and Seniha "live under the sway of passions and desires." As "the discrepancy between what they expect and hope and what comes true and is realized" grows, they feel unhappy and desperate, also suffering a lot (Tolan, 1881, p. 21). This mood invariably puts them under the psychological pressure of their dreams and as a result, they cannot achieve satisfaction (p. 21). As Emile Durkheim defined, they are "a bunch of infinitely sensitive passions and tendencies" (p. 35). He also commented that once they cross the natural limits, nothing can prevent them from going astray; new passions give birth to the others and these trigger the intelligence naturally. Intelligence, however, shows these passions new targets that provoke and steam them up. The satisfaction produced by these passions makes them more indispensable and insatiable (p. 36). Nothing is of meaning in the space where they are. This is because "their own realities, or dreams, are much different from the general social realities" (p. 127). This, in turn, fuels "the sense of meaninglessness."

\section{Emma and Seniha}

Emma's dreams start with the books that she secretly reads in her years at the monastery. It is at the age of fifteen that she fouls her hands with the oily dust of the books that she has read, and never again will she be left without that dust.

She would have liked to live in some old manor-house, like those long-waisted chatelaines who, in the shade of pointed arches, spent their days leaning on the stone, chin in hand, watching a cavalier with white plume galloping on his black horse from the distant fields... (Flaubert, 1996, p. 53)

Everything she sees in the books shines in her dark life like the comet in the sky, which is also equally far. She is aware that if she is to realize her dreams, she should go away from the farm where she lives. It is just for this reason that she agrees to marry Charles, who she believes will save her from the farm and help her attain the living conditions she builds in her dreams. To her, he will make a husband who knows anything she dreams of, who is versatile in many fields, and who will teach a woman the power of passion, the niceties of all secrets and the way of living in grace (Horney, 1999, p. 117). However, her expectations fail and Charles brings upon Emma nothing but disappointment and regret.

Finally, a door opens part way into the life in her dreams, or books. They take an invitation for a ball from Marquis d'Andervillier, who has got one of the titles in the books she has read. This moment is the turning point of her life. In Marquis's chateau, Emma finds herself in the middle of the life that she has found in the books. The smell of this new space warms her up. She feels as if she were in another world, and even universe. Nothing around her is similar to the one in real life. Everything and everybody seems to have sprung from the books. They have seen different countries and palaces. Everything is luxurious. There she tastes many things that she has never tasted before. She even finds the granulated sugar whiter than the one everywhere else. She feels herself walking in the air. The dream of Cinderella has now come true. She recalls the past as darkness. On the way to alienation from herself, her tie with her past is disconnected at that moment. She wishes this spell would never be broken and she could live in this way all her life. She has come into the life of her dreams. Under the spell of this reality she hopes to be engaged in those around her and her dreamlike life which is now 
realized (Flaubert, 1996, p. 68). These thoughts of hers detract her well from the monotonous life which she has had to lead in reality. Now she is away both from the life in her dreams that has come true momentarily and from the real life in which she is.

The spell is broken the next morning. They leave Vaubyessard, the space of dreams, for Tostes, the space of reality. Emma compares the ball with her real life:

Her journey to Vaubyessard made a hole in her life, like one of those great crevices that a storm will sometimes make in one night in mountains. (Flaubert, 1996, p. 70)

The only thing that proves that the ball is not a dream is the green silk tobacco case that Charles has found. Under the influence of the joy of having touched her dreams, she does her best to adapt to the real life. Much as she does anything possible for adaptation, she cannot do so because she is so much absorbed in the dream world that it is no longer possible for her to give them up and return to the real world.

On the other hand, Seniha likes reading the novels of Gyp, new dramatic plays and entertaining papers of Paris. Gyp becomes the second tutor to her. She emulates the free, semi-male and semi-female young girls that she reads in novels. It is her greatest passion to be like them (Karaosmanoğlu, 1999, p. 57). She tries to adapt these young-girl types to her life by the evening. However, the circumstances in which she is prevent her from doing so. The impossibility of realizing her dream pushes her into nervous crisis and breakdown.

She seems to be caught in a storm. Seconds and minutes hit her face and chest like a tornado in such a way as to be short of breath. Her body resembles a piece of twisted tether. Her voice and breath are squeezed among her teeth and her nails stick into her palm like a dagger. (Karaosmanoğlu, 1999, p. 53)

Both for Seniha and Emma, the place where the dreams can be realized is Europe/Paris. And now Seniha does everything to appease her longing for Europe; her visits, her entertaining the guests, her jumping from one shop to another, her dances, her make-ups and all sorts of madness.

The festivals and the bright cities of Europe were attracting her in a magical way. To Seniha Europe was what a mirage is to those who tread the desert. (Karaosmanoğlu, 1999, p. 55)

God knows what Paris is like. Even its name gives Emma infinite pleasures and joys.

She repeated it in a low voice, for the mere pleasure of it; it rang in her ears like a great cathedral bell; it shone before her eyes, even on the labels of her pomade-pots. (Flaubert, 1996, p. 71)

In her dreams, she pursues those who go to Paris through the meadows below the stars and beyond the hills. She comes to a place though she does not know what and where it is. Her dreams cannot go much beyond. Her destiny has nailed her where she currently is. She takes a map of Paris so as to satisfy her yearning for Paris. Putting and dragging her finger on it for hours, she walks throughout the city in her dreams. She spends hours in the streets, stopping on every corner. She closes her eyes when she is too tired.

At last she would close the lids of her weary eyes, and see in the darkness the gas jets flaring in the wind and the steps of carriages lowered with much noise before the peristyles of theatres. (Karaosmanoğlu, 1999, p. 72)

She wishes at the same time "to die and to live in Paris" (Karaosmanoğlu, 1999, p. 74).

These two women are not in agreement with themselves and thus have difficulty contacting with the people around them. They desire to leave the space they are in, and they avoid meeting and talking to the people surrounding them. In a sense, they appear to be "giver", but this is only for the purpose of taking 
something in return for it. It is not the people they face but their own benefits that they think of and focus on. It would not be wrong to say that they show them "as an extension of their own ego, or self" (Gectan, 1984, p. 83). They are filled with hatred and anger and even antagonism. Everything is abhorrent to them. This abhorrence is caused by their awareness of the gap between their dreams and their real satisfaction. The failure of their own dreams and "their emulation for others" make Seniha and Emma sensitive. As they cannot find the chance to realize their dreams, they feel hurt and injured, and so they become totally antagonistic to other people. At this point, however, they take shelter in their dreams once more again. This shelter, in turn, feeds their selfishness and hatred.

Where Seniha lives, she cannot find the life she longs for. The reality is quite unlike her dreams.

There are no movements and no words from those around her that do not appear ridiculous! (Karaosmanoğlu, 1999, p. 26)

Bored and embarrassed with their words, she cannot talk to them for long. It is because she does not give an ear to them, nor does she try to understand them. Consequently, her disharmony and disconnection push him into seclusion in her room.

Seniha wreaks all her anger on the piano. She is attracted to the piano both because she feels she has nothing to talk with those around her and because she finds them inferior and alien to her own world. She prefers to lay the piano rather than talk. It is not only that she does not understand them but also that they do not communicate with her. Therefore, she has only one distinguishable response to her environment; aggressiveness (Karaosmanoğlu, 1999, pp. 34-40). She melts like "a bundle of lily thrown aside" in a space where she feels alienated. There is a melting in her soul, as well. She is lonely; she feels choked in the house. It suffocates her. She is not quite unlike a grave. She is out of breath; she wants to hurl into the streets to have her voice heard, screaming (Karaosmanoğlu, 1999, p. 39). Everything is narrow, scarce and ordinary. The furniture in the house is not in the order and way she likes. The disharmony between the house, people and Seniha grows day by day. How big her alienation has grown is clear in these words:

Her grandfather, mother and even father seem to her like a variety of living creatures whose language she did not understand and whose behaviors she was scared of. (Karaosmanoğlu, 1999, pp. 37-39)

As for Emma's experience, it can be seen as follows:

All her immediate surroundings, the wearisome country, the middle-class imbeciles, the mediocrity of existence, seemed to her exceptional, a peculiar chance that had caught hold of her, while beyond stretched, as far as eye could see, an immense land of joys and passions. (Flaubert, 1996, p. 73)

She has a world of happiness and love extending beyond her own into other spaces, for example her dream world.

Emma's alienation, hatred and anger become more noticeable upon her marriage to Charles. She resorts to marriage as a means of getting rid of the space abhorrent to him (Flaubert, 1996, p. 56). Nevertheless, there is no hint of happiness in her marriage. Emma is again lonely in her world of dreams. The sense of alienation into which she is drifted in the farm goes on without losing its impetus even a while (p. 51). She wants to see in Charles whatever she reads in books. She wreaks all her vengeance on the piano, strongly hitting on the ivories and letting her fingers walk across them incessantly and vengefully (p. 57). Like the colors of black and white, her dreams and the realities are very far apart; alienation reaches its zenith gradually. 
Disharmony and disconnectedness are followed by revolt against the space inhabited. Living, and indeed having to live, in places to which they do not feel they belong and which they feel they do not deserve afflicts and grieves these two women. They rebel. They do struggle to find and live the happiness and harmony in other places, which are their individual worlds that they have already created to their own taste and expectations. Anything they do and try to do is a preparation for their dreams which they hope to realize one day eventually.

Seniha rebels her grandfather frequently, criticizing everything around her. She is weary of traditions. She aspires after a very different and higher-up luxurious life. Emma also occasionally rebels her father's will to adhere to traditions. She, for example, strongly opposes her father's thought about the wedding. Yet it becomes her father that imposes his wishes (Flaubert, 1996, p. 60). She is unhappy in her father's farm. What she is expected to do there is not her cup of tea. It does not take her long to loathe the village life after her return from the monastery to the farm. She thinks that there has remained nothing to learn and feel in life (p. 43).

There are very few moments when Seniha and Emma give the impression that they have broken the chain of social alienation. Both of them talk only to those who have experienced the life in their dreams. This is different from a real communication. They are lonely in crowd; they are content only with listening to others who add nothing to the communication between them. They feel closer to their dreams at those moments, achieving satisfaction to some extent. However, it should be added that they communicate not with those real people, but with the stories they tell. They are entranced then and live in dreams. Psychologically they are away from where they physically are.

It is from the doors, walls and furniture that Seniha invites her growing hatred and vengeance towards where she lives and those who share it with her. She is all in a fluster like a caged bird. Where she lives in her inner world distresses and whelms her (Flaubert, 1996, p. 56). She loves the luxury and European life style. Unlike Emma, she gathers together the people who have attained the life in their dreams (Karaosmanoğlu, 1999, p. 28).

Both Seniha and Emma always spend money and do shopping in order to get rid of their alienation and to achieve satisfaction. There are "many dresses which are out of fashion, losing their vivid colors though never worn, and many pairs of shoes that have remained for years as they first came from the shoe seller" (Karaosmanoğlu, 1999, p. 41). The handkerchiefs, gloves, socks and such pieces that have been bought and thrown aside without wearing heap up, but even so she regards herself as being among the poorest of the world. After a while even the books begin not to console and cheer her up. She has a fit and faint, breathing the same air (p. 52).

Emma's wardrobe "had a lot of shoes. Charles could not dare give her a little warning, so she would chuck the money around as she liked to" (Flaubert, 1996, p. 196). Parallel to her growing hatred for Charles is her fondness for money and shopping. Even though she has no money to pay, she constantly gives orders to $\mathrm{Mr}$ Lheureux. Her debts increase day by day, but she tells lies to Charles about money.

Another indicator of alienation is the monotonousness in their real life. Not even a single moment is different in the lives of Seniha and Emma. What they will do and how their days will pass seem to have been prearranged. Everything is the same and boring as it was the previous day.

Emma's marriage has already been captivated by the monotonous wheel of marriage. It is clear and known what time of the day Charles will embrace Emma. It is something like a dessert to be eaten after the meals. The new friend that she finds to avoid loneliness is a hound. On the never-changing dusty road in the garden walks she with her hound. She hates Charles (Flaubert, 1996, pp. 57-60). 
In both novels, social alienation is followed by self-alienation. Seniha and Emma's true selves are different from their attitudes to people around them and their identities. They are indeed alienated to their essence. They want to be like the characters they read in the books, not what they themselves are. They are away from perceiving the real world and taking lessons from their experiences. They wear a number of masks on the level of alienation. This mask-wearing experience alienates the young women from themselves (Geçtan, 1984, p. 57).

When it comes to their dreams, even a small spark breaks their balance. They can never be what they are. Their benefits remove and alienate them from themselves. They are quick to lapse into a change, so much so that while they are someone now, they can be someone else in a minute:

The fact that they are alienated to themselves makes it possible for them to change their personalities in accordance with the needs of the environment. Like a chameleon, they always play a role in life without realizing that they do this, and like actors who do well, people produce feelings and sentiments suitable for their roles. (Horney, 1999, p. 203)

The method of treatment planned for Seniha and Emma is the same: Sending them to another place. Both for Seniha and for Emma, a new place means a new beginning, thus a new hope. They get closer to their dreams in their new places. They grow away from their true selves and play the lovers in the books they read.

Both Seniha and Emma regard men as an "investment" that will help them get rid of alienation. These men are alike. Faik Bey stands for Rodolphe, and Hakkı Celis for Leon. Trying to show themselves as quite unlike who they really are, Seniha and Emma share the same destiny on the level of social alienation and self-alienation. Yakup Kadri Karaosmanoglu (1999) makes certain the similarity between Seniha and Emma in his novel:

Hakk1 Celis began to suspect that Seniha really existed once upon a time; this girl was one of the fictitious girls known to the young man from the books: in his imagination, (...) she mingled in many like Madame Bovary. (p. 191)

\section{Conclusion}

As shown above, the novels Madame Bovary and Kiralık Konak are so close to each other in the sense of alienation of the protagonists. Both novels are centred round a female protagonist who passes through all the stages of alienation on the way to the way of life they dream of. The problems in which they thrash about get bigger day by day, only to lead them to unhappiness, hopelessness, helplessness and finally destruction. Each step they take prepares the ground for their alienation first from those around them and the society and then from themselves. They experience almost the same ends however different they may appear. Happiness will remain an impossible-to-reach target for both. Emma resorts to suicide as the last stage of alienation. The reason for her subjection to incessant grief as well as dissatisfaction and her choice of suicide is the gap between her dreams and realities. Seniha, on the other hand, insists on living on in a neurotic vicious cycle as her attempts always end up failure and dissatisfaction. The result for both of them is disillusionment.

\section{References}

Cevizci, A. (1996). Felsefe Sözlüğ̈̈ (A Dictionary of Philosophy). Ankara: Ekin Yayınları.

Ergin, S. (1983). Modern Amerikan Şiirinde Yabancılaşma (Alienation in modern American poetry). İzmir: Ege Üniversitesi Edebiyat Fakültesi Yayınları.

Flaubert, G. (1996). Madame Bovary (Madame Bovary). (N. A.-S. E. Siyavuşgil, Trans.). İstanbul: Remzi Kitabevi.

Geçtan, E. (1984). Insan Olmak, varoluşun bireysel ve toplumsal anlamı (Being Human; the individual and social meaning of existence). İstanbul: Adam yayınları. 
Horney, K. (1999). Nevrozlar ve insan gelişimi, öz gerçekleştirme kavgası (Neurosis and human development, struggle for self-actualization). (S. Budak, Trans.). Ankara: Öteki Yayınevi.

Karaosmanoğlu, Y. K. (1999). Kiralık Konak (The mansion for sale). İstanbul: İletişim yayınları.

Tolan, B. (1881). Çağdaş toplumun bunalımı, anomi ve yabancılaşma (Anomaly and alienation; crisis of the modern society). Ankara: Ankara İktisadi ve Ticari İlimler Akademisi Yayınları. 